\title{
EXTRACTION OF METAL IONS FROM SOLUTIONS AFTER LEACHING OF SPENT NiMH BATTERIES
}

\author{
Bernadeta GAJDA \\ Czestochowa University of Technology, Institute of Metallurgy and Metal Technology, Poland, EU, \\ gajda@wip.pcz.pl
}

https://doi.org/10.37904/metal.2019.944

\begin{abstract}
In the recent years, the amount of waste has been drastically increasing, affected on the environment. On the other hand, there is observed a shortage of metals associated with the increase in their use and depletion of their natural resources. NiMH batteries. NiMH batteries contain, among nickel, cobalt, lanthanum, neodymium and other important metals. One of the possible and effective methods used for the metals recovery are hydrometallurgical processes, i.e. leaching and solvent extraction for metal separation. This work presents the results of the $\mathrm{Zn}(\mathrm{II}), \mathrm{Co}(\mathrm{II}), \mathrm{Ni}(\mathrm{II}), \mathrm{La}(\mathrm{III}), \mathrm{Ce}(\mathrm{IV})$ separation by solvent extraction. The source of metals was the solution from leaching of $\mathrm{NiMH}$ batteries. In the extraction process, chosen organic acids like, bis $(2,4,4-$ trimethylpentyl) phosphinic acid (Cyanex 272), bis(2,4,4-trimethylpentyl)ditiophosphinic acid (Cyanex 301), bis(2,4,4-trimethylpentyl)tiophosphinic acid (Cyanex 302) and di(2-ethylhexyl)phosphoric acid (D2EHPA) were used as the extractant.
\end{abstract}

Keywords: Solvent extraction, rare earth elements, nickel-metal hydride batteries

\section{INTRODUCTION}

In recent years, an increase in the amount of waste is observed, and this is a tremendous problem for the environment. Beyond that natural resources of many valuable natural elements are shrinking, which generates the need to search for other solutions, namely for such as those, which will employ secondary sources. Such waste as used batteries, for example NiMH batteries, are a valuable source containing many metals, such as: nickel, cobalt, manganese, copper and -what is the most precious - rare earth elements (REEs). The critical metals are defined as metals which natural resources do not cover their wider use, for example for the production of solar panels, permanent magnets, catalysts, fuel cells, plasma screens or touch screens, etc. Critical metals - among which are, in particular, REEs and cobalt - are metals whose natural resources do not meet the demand, which causes the necessity of importing them or searching for secondary sources. Used NiMH batteries contain - inter alia - such metals as: nickel, cobalt, manganese and lanthanides, namely: lanthanum, neodymium, promethium, yttrium and cerium. Larsson et al. [1] indicated that the anode in this type of batteries is a metal alloy (Mischmetall - "mixed metal") described by the formula: $\mathrm{Ni}_{4.15} \mathrm{Co}_{0.29} \mathrm{Mn}_{0.44} \mathrm{Al}_{0.12} \mathrm{La}_{0.65} \mathrm{Ce}_{0.24} \mathrm{Nd}_{0.08} \mathrm{Pr}_{0,03}$ with additions $\mathrm{Y}_{2} \mathrm{O}_{3}$. The following metals are contained in the cathode: $82.9 \mathrm{wt} \%$ of nickel, $12.4 \mathrm{wt} \%$ of cobalt, $1.1 \mathrm{wt} \%$ of zinc, $0.7 \mathrm{wt} \%$ of magnesium, $0.4 \mathrm{wt} \%$ of manganese and $1.9 \mathrm{wt} \%$ of yttrium.

Recovering metals that belong to the REEs is of particular importance, due to the fact that they are more and more widely used (for example in mobiles, drones, TV sets, etc.) and - at the same time - there is a lack of their natural deposits in Poland. Furthermore, waste batteries are classified as hazardous waste that is subject to special treatment. Application of hydrometallurgical processes, such as the leaching process [2-5], solvent extraction [6-9], membrane processes or ion exchange [10] in order to recover metals from this type of secondary raw material is a very efficient and future-oriented task. In the processes used for recovery and separation of metals, it is of crucial importance to select proper extractant. Among rare earth metal extractants that are used in extraction processes are such organophosphorus acids as: 2-ethylhexyl phosphoric acid-2ethylhexyl ester (EHEHPA), di-(2-ethylhexyl) phosphoric acid (D2EHPA), tributyl phosphate (TBP), and others 
[11]. The objective of this research study was to determine the applicability of extractant from the organophosphoric acid group for the process of selective extracting such metals as: Zn, Fe, Ni, Co, La, Ce, $\mathrm{Mn}$ and $\mathrm{Al}$ from acidic chloride solutions obtained after leaching from used $\mathrm{NiMH}$ batteries. The impact of $\mathrm{pH}$ increase in the feed phase on the efficiency of selective separation of metals was also subject of the research tests.

\section{MATERIALS}

Waste solution collected after the hydrochloric acid leaching process of used $\mathrm{NiMH}$ batteries from various producers served as the test material (Figure 1). The batteries were cut into small pieces and crushed without removing their steel case. Various concentrations of $\mathrm{HCl}$ were used as a leaching agent in the leaching process. The solution obtained after tests performed on the battery during the leaching process was used for solvent extraction. The initial solution was diluted 10 times and afterwards divided into two parts. In the first part, the measured level of $\mathrm{pH}$ was 1.6; and in the second part, the $\mathrm{pH}$ was being increased by using the $\mathrm{KOH}$ solution to receive the value of 3.0. Consequent increase of the $\mathrm{pH}$ level caused precipitation of iron hydroxides. Table 1 presents concentrations of metal ions observed in the solution used for the extraction process.
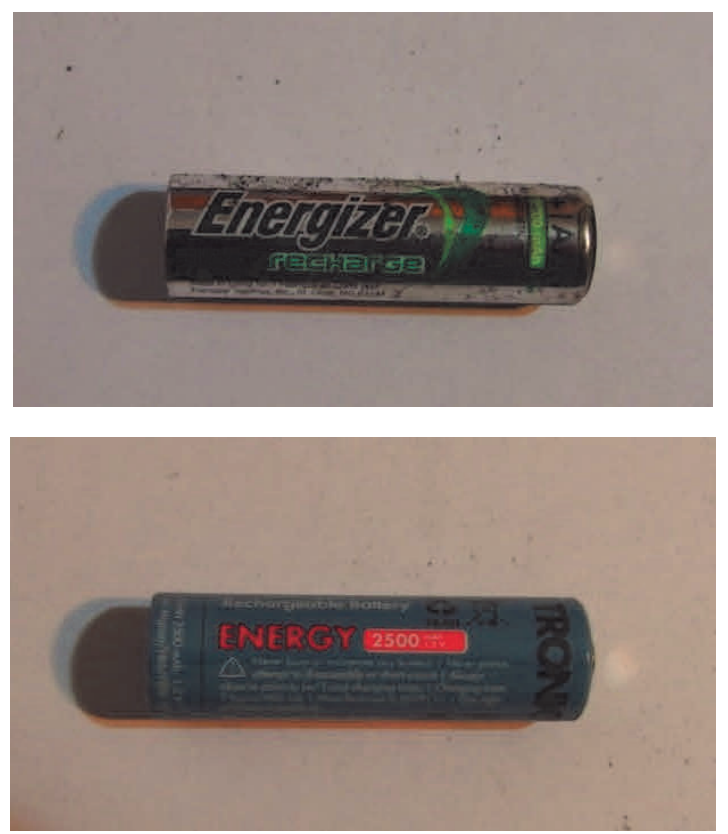
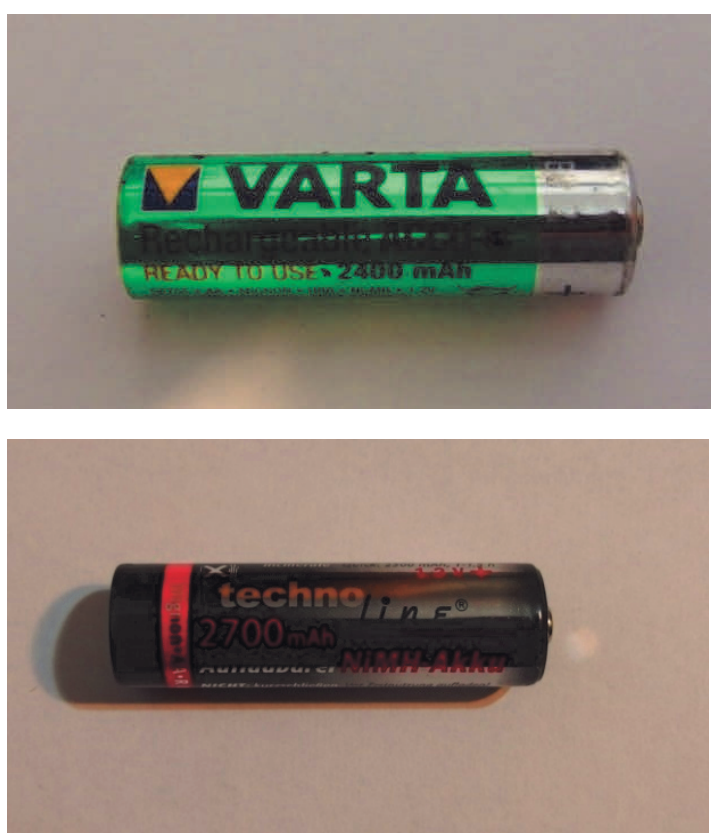

Figure 1 Examples of used $\mathrm{NiMH}$ batteries from various manufactures

Table 1 Concentration of metals in the solution used in the extraction process

\begin{tabular}{|l|c|c|c|c|c|c|c|c|}
\hline Metal & Zn(II) & Fe(III) & Ni(II) & Co(II) & La(III) & Ce(III) & Mn(II) & Al(III) \\
\hline Concentration of metal $\left(\mathrm{mg}^{\prime} \mathrm{dm}^{3}\right) 10^{-3}$ & 0.1 & 3.5 & 10 & 0.9 & 0.8 & 0.02 & 0.4 & 0.37 \\
\hline
\end{tabular}

\section{EXTRACTION PROCESS}

The aqueous phase in the process was a chloride solution with a $\mathrm{pH}$ of 1.6 and 3.0, respectively. The organic phase consisted of extractant solutions, namely the Di-(2-ethylhexyl) phosphoric acid (D2EHPA), bis(2,4,4trimethylpentyl) phosphinic acid (Cyanex 272), bis(2,4,4-trimethylpentyl)thio-phosphinic acid (Cyanex 302) and bis(2,4,4-trimethylpentyl) dithiophosphinic acid (Cyanex 301) with $0.05 \mathrm{M}$ concentration of refined petroleum (Aldrich). The ratio of both phases was $10 \mathrm{ml} / 10 \mathrm{ml}$. Both phases were shaken in a conical flask by a shaker 
for a period of $15 \mathrm{~min}$, and then allowed to stand for 12 hours. After this period of time, both phases were separated and a sample for analysis was taken from the aqueous phase. The concentration of metal ions in the leach aqueous solutions was determined by atomic emission spectrometry method (spectrometer MP-AES 4200, made by Agilent).

The extraction percentage was determined is equal to:

$\% E=D /(D+1) 100 \%$

Where the distribution coefficient, D, was taken as the ratio of the concentration of metal in organic and aqueous phases:

$D=[M]$ org $/[M]$ aq

\section{RESULTS AND DISCUSSION}

Results of the extraction process from chloride solution with $\mathrm{pH}=1.6$ by using extractants from the group of organophosphorus acids are shown in Figures 2-5. The initial composition of the aqueous phase is presented in Table 1. Figures 2-5 indicate on the dependence of extraction efficiency of the separated metal ions depending on the extractant used.

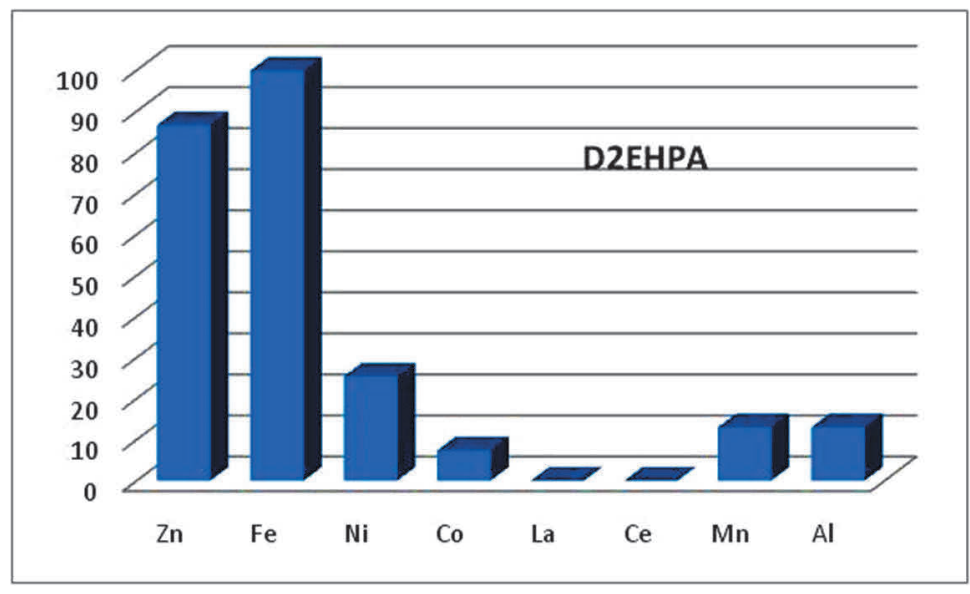

Figure 2 The efficiency of extraction of metals ions from the chloride solution. The aqueous phase: chloride solution, $\mathrm{pH}-1.6$. The organic phase: $0.05 \mathrm{M}$ solution of D2EHPA in kerosene

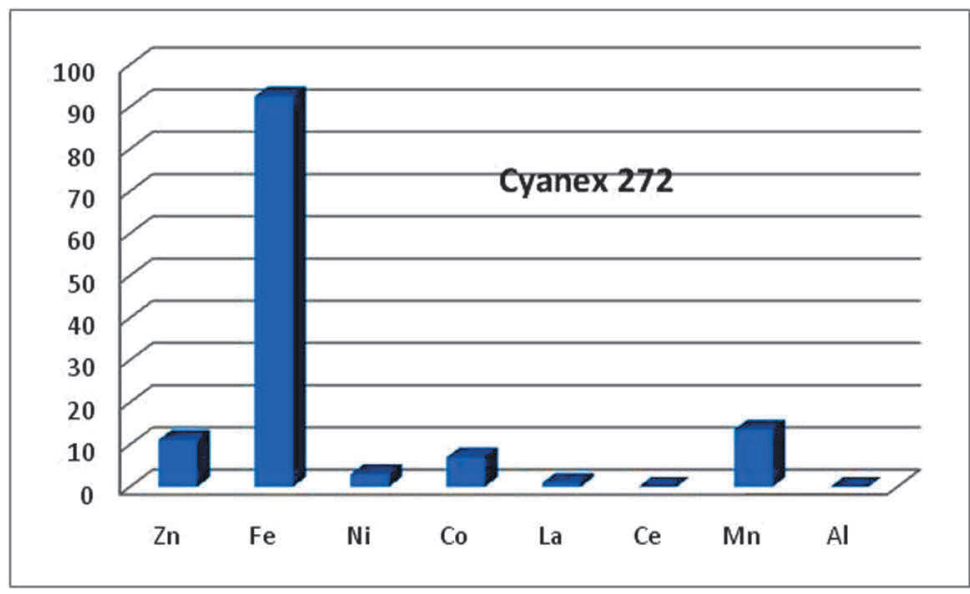

Figure 3 The efficiency of extraction of metals ions from the chloride solution. The aqueous phase: chloride solution, $\mathrm{pH}-1.6$. The organic phase: $0.05 \mathrm{M}$ solution of Cyanex 272 in kerosene 


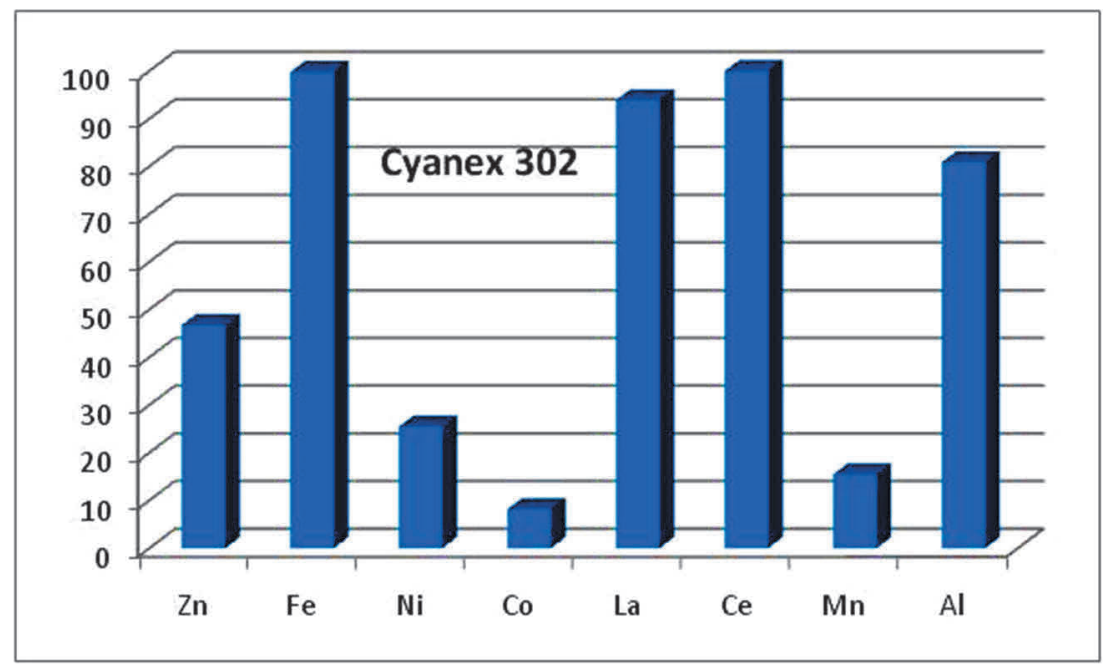

Figure 4 The efficiency of extraction of metals ions from the chloride solution. The aqueous phase: chloride solution, $\mathrm{pH}-1.6$. The organic phase: $0.05 \mathrm{M}$ solution of Cyanex 302 in kerosene

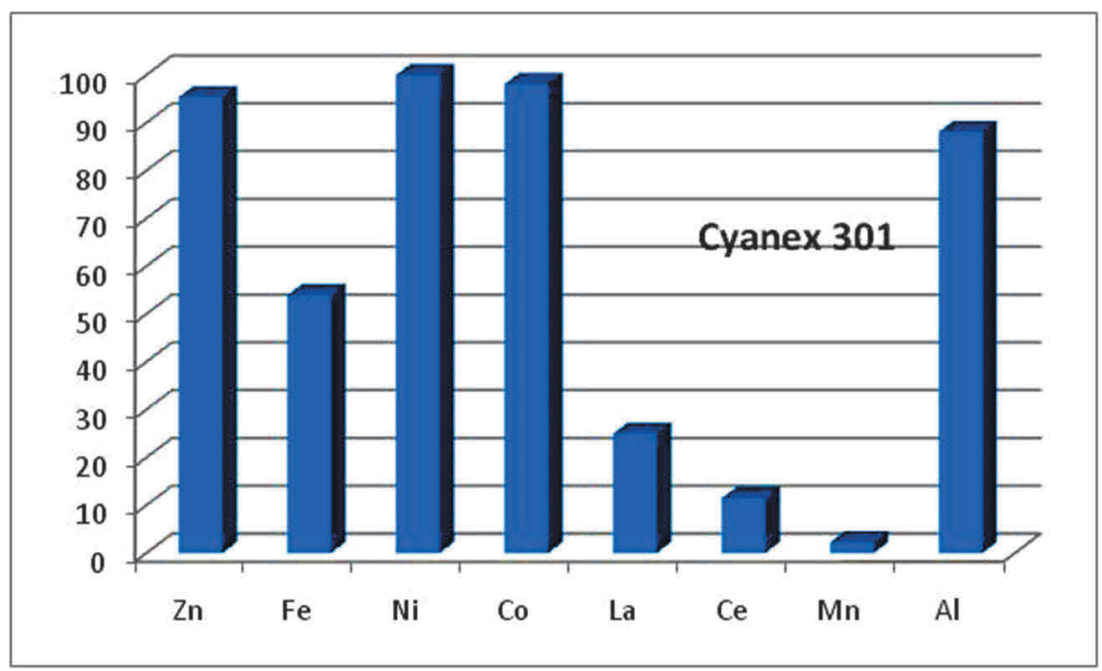

Figure 5 The efficiency of extraction of metals ions from the chloride solution. The aqueous phase: chloride solution, $\mathrm{pH}-1.6$. The organic phase: $0.05 \mathrm{M}$ solution of Cyanex 301 in kerosene

Application of D2EHPA as an extractant allowed for separation of Fe and $\mathrm{Zn}$ with almost $100 \%$ efficiency. The efficiency of $\mathrm{Ni}, \mathrm{Co}, \mathrm{Mn}$ and $\mathrm{Al}$ extraction did not exceed $25 \%$ of the total efficiency level, whereas, the lanthanum and cerium ions under such conditions remained in the aqueous phase. This process allowed to separate iron and zinc from the mixture. From a solution with the initial $\mathrm{pH}$ of 1.6, Cyanex 272 effectively extracted iron, while the remaining metal ions stayed in the aqueous phase. The extraction efficiency of $\mathrm{Zn}$, $\mathrm{Fe}, \mathrm{Ni}, \mathrm{Co}, \mathrm{La}, \mathrm{Ce}, \mathrm{Mn}$ and Al metals by using Cyanex 302 received the level of approx. 49, 100, 25, 8, 94, 100,15 and $81 \%$, respectively. The results demonstrate that some of the metals can be efficiently separated, and therefore, the second stage of extraction can be applied for separation of the remained metals. By applying the Cyanex 301, Ni, Co, Al and $\mathrm{Zn}$ can be almost completely removed, however $\mathrm{La}, \mathrm{Ce}, \mathrm{Mn}$ and $\mathrm{Fe}$ are left in the feed solution. In this case, as well, application of the second stage of extraction would allow to increase selectivity of the process.

Due to the fact that acidity of the initial solution can affect the efficiency level of metal extraction and selectivity of the process, as well, there was also performed extraction from a solution with raised level of pH up to 3.0. Table 2 presents results of these research tests. 
Table 2 The extraction efficiency of metals extracted from chloride solution at $\mathrm{pH}=3$ using $0.05 \mathrm{M}$ extractant solutions in kerosene

\begin{tabular}{|c|c|c|c|c|c|c|c|c|}
\hline \multirow{2}{*}{ Extractant } & \multicolumn{8}{|c|}{ Extraction efficiency (\%) } \\
\cline { 2 - 9 } & Zn & Fe & Ni & Co & La & Ce & Mn & Al \\
\hline D2EHPA & 95.5 & 100 & 31 & 40 & 100 & 100 & 64.6 & 100 \\
Cyanex 272 & 70.5 & 100 & 3 & 43 & 11 & 91.2 & 10 & 10 \\
Cyanex 302 & 95.6 & 99.1 & 28.4 & 46.8 & 30.6 & 96.2 & 95.5 & 97 \\
Cyanex 301 & 89.4 & 99.9 & 99.4 & 99.7 & 99.1 & 97.6 & 22.8 & 100 \\
\hline
\end{tabular}

By raising the $\mathrm{pH}$ level in the initial solution, extraction efficiency of metal ions in the solution was significantly improved. Many of them have reached $100 \%$ efficiency of extraction. Unfortunately, selectivity of the process has significantly deteriorated. The results call for introduction of a multi-stage extraction, which would probably lead to efficient and selective separation of metals from the solution. It also seems likely that by removing the steel casting from the material used in the leaching process, the presence of iron ions in the solution could be eliminated. This, in turn, would allow to raise the $\mathrm{pH}$ level in the initial solution, and this could further increase the extraction efficiency.

\section{CONCLUSIONS}

Results presented in the study have demonstrated that all of the used extractant can be applied in the extraction process of metals, namely: $\mathrm{Zn}, \mathrm{Fe}, \mathrm{Ni}, \mathrm{Co}, \mathrm{La}, \mathrm{Ce}, \mathrm{Mn}$ and $\mathrm{Al}$ from solutions obtained by leaching used $\mathrm{NiMH}$ batteries by using hydrochloric acid. Due to the fact that in the solution were present as many as eight metals, the extraction process should be followed in several stages. Results indicated on the need to carry out further research study in this area. At the same time, it can be concluded that the presence of ion in the solution could be eliminated by removing the steel casing prior to the leaching process, and this could contribute to improving the selectivity of the process, being subject to the research study.

\section{REFERENCES}

[1] LARSSON, K., EKBERG, Ch. and ÅDEGAARD-JENSEN, A. Dissolution and characterization of HEV NiMH batteries. Waste Management. 2013. vol. 33, pp. 689-698.

[2] CHUL-JOO, K., HO-SUNG, Y., KYUNGWOO, Ch., JIN-YOUNG, L., SUNG-DON, K., SHUN MYUNG, S. et al. Leaching kinetics of lanthanum in sulfuric acid from rare earth element. Hydrometallurgy. 2014, vol. 146, pp. 133137.

[3] XIA, Y., XIAO, L, TIAN, J., LI, Z. and ZENG, L. Recovery of rare earths from acid leach solutions of spent nickelmetal hydride batteries using solvent extraction. Journal of Rare Earths. 2015. vol. 33, no. 12, pp. 1348-1354.

[4] GAJDA, B., GĘGA, J., KOŁODYŃSKA, D. and HUBICKI, Z. Preliminary research of leaching of spent NiMH batteries with chosen organic acids. In METAL 2017, 26th International Conference on Metallurgy and Materials. Ostrava: TANGER. 2017. pp. 1714-1719.

[5] PIETRELLI, L., BELLOMO, B., FONTANA D. and MONTEREALI, M. Characterization and leaching of NiCd and $\mathrm{NiMH}$ spent batteries for the recovery of metals. Waste Management. 2005. vol. 25, pp. 221-226.

[6] LARSON, K., EKBERG, Ch. and ÅDEGAARD-JENSEN, A. Using Cyanex 923 for selective extraction in a high concentration chloride medium on nickel metal hydride battery waste. Hydrometallurgy. 2012. vol. 129-130, pp. $35-42$.

[7] PROVAZI, K., AMARAL CAMPOS, B., CROCCE, D., ESPINOZA, R., ALBERTO, J. and TONORIO, S. Metal separation from mixed types of batteries using selective precipitation and liquid-liquid extraction techniques.

Waste Management. 2011. vol. 31, pp. 59-64. 
[8] INNOCENZI, V. and VEGLIO F. Separation of manganese, zinc and nickel from leaching solution of nickel-metal hydride spent batteries by solvent extraction. Hydrometallurgy. 2012. vol. 129-130, pp. 50-58.

[9] ZHANG, P., YOKOYAMA, T., ITABASHI, O., WAKUI, Y., SUZUKI, T. and INOUE, K. Hydrometallurgical process for recovery of metal values from spent nickel-metal hydride secondary batteries. Hydrometallurgy. 1998. vol. 50, pp. 61-75.

[10] KOŁODYŃSKA, D., FILA, D., GAJDA, B., GĘGA, J. and HUBICKI, Z. Applications of lon Exchange Materials in the Environment. Eds. Inamuddin, M. Imran Ahamed, A. M. Asiri, Springer, Switzerland, 2019. pp. 161-185.

[11] HAILONG, H., JIANHONG, X., YOUNDONG, W. and JINNAN, C. Solvent extraction of lanthanum and cerium ions from hydrochloric acidic aqueous solutions using partly saponified 2-ethylhexylphosphonic acid mono-2ethylhexyl ester. Chinese Journal of Chemical Engineering. 2016. vol. 24, pp. 79-85. 